\title{
Local self-government in public and private law: latest experience
}

\section{Місцеве самоврядування у публічному та приватному праві: останні тенденції}

Received: May 4, 2021

\begin{abstract}
Local self-government is one of the major institutions of civil society. Most democracies in the world have a developed system of local selfgovernment, to which a number of state functions are delegated. To characterize this institution and clarify its inherent features of private and public law, it is necessary to study modern systems of local self-government and theoretical achievements in the field of private and public law. The work aims to analyze local selfgovernment given the features inherent in public and private law. The object of research is local self-government in public and private law. The following methods were used during the study: analysis of regulations, articles and monographs, comparisons, abstractions, analogies, and generalizations. The study of the question of the attribution of local self-government as a subject of law to private and public law revealed a number of features that are characteristic of both public and private law. Based on the analysis of the scientific literature, the main characteristics of the system of local self-government in the world are determined, in particular, on the example of such countries as the USA, Great Britain, France, and Japan. Based on the theoretical achievements of legal scholars on private and public law, it was possible to identify their differences, basic features and, on this basis,
\end{abstract}

Accepted: June 10, 2021

Written by:

Boris Perezhniak $^{74}$

https://orcid.org/0000-0002-4096-0861

Alina Hryshchuk ${ }^{75}$

https://orcid.org/0000-0001-6289-6656

Iryna Menso ${ }^{76}$

https://orcid.org/0000-0003-0211-1567

Kristina Strukova ${ }^{77}$

https://orcid.org/0000-0001-7769-7692

Arkadii Nazarko ${ }^{78}$

https://orcid.org/0000-0001-8041-2758

\footnotetext{
${ }^{74}$ Doctor of Legal Science, Professor of Constitutional Law Department of National University "Odesa Law Academy", Honored Lawyer of Ukraine, Academician of the National Academy of Sciences of Higher Education of Ukraine, Ukraine.

${ }^{75}$ Ph. D., Associate Professor of the Department of Administrative and Legal Disciplines of the Institute of Law of Lviv State University of Internal Affairs, Ukraine.

${ }^{76} \mathrm{Ph}$. D., Senior Lecturer of Civil and Labor Law Department, Odesa National Maritime University, Ukraine.

${ }^{77} \mathrm{Ph}$. D., Lawyer.

${ }^{78}$ Ph. D., Associate Professor of Constitutional Law Department of National University "Odesa Law Academy", Ukraine.
} 
to conclude that local government is characterized by features of both private and public law.

Keywords: local self-government, private law, public law, cooperation, interconnection, opposites.

\section{Introduction}

From ancient times the terms "public and private" were used as opposite in meaning. In the history of jurisprudence, both theoretical and practical, the attention to the study of these "opposites", to clarifying the criteria for distinguishing between the two parts of objective legal law and, of course, to find common features and common boundaries. The current stage of development of society and legal thought is characterized, in particular, by an appeal to clarify the difference between public and private law.

The division of law into public and private in modern jurisprudence is necessary for the classification of legal phenomena, especially in the formation of the legal system, but requires a caveat on two crucial points.

First, although the law as a whole has an official, state, and, in this sense, public character, it should be borne in mind that the term "public" can be used in jurisprudence also in a narrower sense. In this sense, the term "public" refers only to that part of the law that relates to the functioning of the state as a subject of legal relations.

Secondly, public law and private law are not branches, but spheres, zones of law, which are, sometimes, called "supra-branches". They cover a group of industries. Public law includes administrative, financial, procedural law, etc.; to private - civil and some other branches of law (Kharytonova, 2002).

As a subject of public law, local self-government in the context of this study finds new features that can be attributed to the field of private law.

Since local self-government is the bearer of local power, the system of local self-government can be defined as one of the forms of direct democracy, which is carried out by the subjects of local self-government. In this case, the subjects of local self-government are participants in municipal relations, which are endowed with legal personality, i.e. legal capacity and legal capacity, which is determined by the rules of municipal law (Baltsiy, 2020). основі цього зробити висновок про притаманність місцевому самоврядуванню рис як приватного, так і публічного права.

Ключові слова: місцеве самоврядування, приватне право, публічне право, співпраця, взаємозв'язок, протилежності.

Recourse to the experience of foreign countries has the opportunity to find solutions to problems in the regulation of relations that arise in the process of activity and organization of the system of local self-government at the national level. It is also necessary to identify those features that will help expand the scientific basis for the study of private and public law.

Each modern legal system has its characteristics, which affect the organization of local selfgovernment. The peculiarity of the RomanoGermanic legal system is the dominance of the normative legal act as a form of law, the division of the legal system into two subsystems - public and private, differentiation and codification of branches of law.

The Romano-Germanic type of legal system covers the countries of continental Europe: France, Belgium, Luxembourg, Spain, Portugal, the Netherlands, Austria, Liechtenstein, Germany, Switzerland, Belgium, etc. The influence of the Romance and German groups of continental law extends beyond Europe: Latin America, Africa, the Middle East, Japan, Indonesia.

Anglo-American type of legal system or common law system - a set of national legal systems that have common features, manifested in the unity of patterns and trends based on the rule formulated by judges in case law, which dominates as a form of law, in the division of common law and the right to justice, in the recognition of the law only after its testing by judicial practice, in the predominance of procedural law over the substantive.

Geography of the common law of the AngloAmerican type, in addition to England and North America - some countries on different continents. The degree of its implementation in these countries varies.

Based on the peculiarities of the construction of the above legal systems, it is advisable to characterize the organization of local selfgovernment as a legal phenomenon. The work 


\section{AMAZONDA}

aims to analyze local self-government given the features inherent in public and private law.

\section{Literature Review}

International documents and works of scholars were used in the study of the essence of local selfgovernment as a phenomenon inherent in the features of public and private law.

Among the scholars who paid attention to the study of local self-government should be noted: Baltsiy (2020), Aranovskyi (2000), Shpak (2014a,b), Kuzmenko (2014), Rovinska (2013), Chaplya (2014), Vorona (2009), and Chirkiv, \& Kushnir (2020).

Thus, based on Baltsiy (2020) work "On the definition of local self-government of Ukraine," a study on this topic, as a bearer of local power, was carried out, the system of local selfgovernment was defined as one of the forms of direct democracy. The subjects of local selfgovernment are participants in municipal relations, which are endowed with legal personality, i.e. legal capacity, which is determined by the rules of municipal law. The author also describes the general characteristics, as a legal institution and the institution of civil society in Ukraine, defines its legislative consolidation at both international and national levels, pays attention to local governments, in particular, they are divided into primary and secondary. The primary subjects of the system include those subjects of legal relations in this field, which directly have the right to decide issues of local importance - these are territorial communities and their members. Secondary subjects of the system should include subjects of legal relations in this field, in which power is derived. Such subjects are characterized by the fact that they are formed by the primary subjects of the system, and, therefore, only through them become potential participants in legal relations in the field of local self-government. Among the secondary subjects, the author singles out the following - village, settlement, city councils; district councils in cities; village, settlement, city mayor; executive bodies of the village, settlement, city council; district and regional councils representing the common interests of territorial communities of villages, settlements, cities; bodies of self-organization of the population.

Moreover, Aranovskyi (2000) is the author of the book "State law of foreign countries", Kuzmenko (2014) - "Administrative law of foreign countries: course of lectures". Based on their provisions, theoretical information on the established system of local self-government in the United States, Great Britain, Japan, and France was used. The presentation of information on the legal regulation of local self-government helped to highlight the main provisions that establish the organization of local selfgovernment at the legislative level. In particular, the Local Government Act, adopted in 1974, defines the basic content of local selfgovernment in Great Britain, in France such a document is the law No. 82-213 of March 2, 1982, an important provision is the provision of Article 1, which can be considered start button of the decentralization process: "Article 1. Communes, departments, and regions are freely governed by elected councils. The laws will determine the distribution of competencies between communes, departments, regions, and the state, as well as the distribution of public funds arising from the new rules of the local tax system and the transfer of state loans to local communities; the organization of the regions, the statutory guarantees provided to the staff of territorial communities, the method of election and the charter of the elected, as well as forms of cooperation between communes, departments and regions and the development of citizen participation in local life."

What is more, Shpak (2014b), in his work "The experience of reforming local government in Britain", considered the concept of parliamentary monarchy, gave basic views on this form of government, analyzed current issues related to the development of local government, administrative division, and hierarchy of power in Britain, competence and responsibilities of local councils.

Further, Chaplya (2014), in his work "Municipal Government in the United States: An Overview", gave a general description of the US local government system, highlighted its features, which include: the presence in each state of a separate system of local government, subordination of local laws to the state, the ability to constantly improve professional the level of providing services to citizens, etc.

Additionally, Vorona (2008) explored the commune as a basic unit of local government in France. In particular, in the framework of this work, data on the powers of the commune were used: financial, in the field of public services, on the property of the commune, powers in the field of landscaping, etc. Regarding the main competencies of regional councils, their competencies include approval of the regional 
budget, control over the implementation of the regional development plan, activities of regional bodies and structures.

To reveal the content of the concepts of private and public law, information was used on the historical aspect of the development of legal thought regarding the division of law into public and private, the criteria for their delimitation, the main features, features of the subject composition. Thus, historical aspects have been studied by such scholars as Shabunina (2006) (considered the division of law into public and private in Roman law), Muromtsev (2003) (studied the civil law of ancient Rome), Nesterenko (2016) studied the main historicaltheoretical doctrines on the division of rights into public and private).

Such sciholars as Skakun (2001), Kharytonova (2002), Sanzharuk (2006), Banchuk (2001), Rabinovych (2004), Mamutov (1999), Nesterenko (2016), and Chepis (2010) studied the criteria for distinguishing public and private law, highlighted their features, in particular, characteristics, characteristics of the subject composition, methods.

\section{Methodology}

The most common way of scientific knowledge is the method of comparison. There are specific requirements for comparison as a method of cognition: only such objects and phenomena must be related, between which there can be a certain objective commonality; comparisons should be made on the most influential, essential grounds. Thus, in the framework of this study, a distinction was made between such concepts as private and public law. Their relationship is of great importance for legal doctrine because it is based on the basic criteria of comparison, in particular, on the subjects, features, methods, and content.

Firstly, the method of analysis of regulations, articles, and monographs helped to find basic information about the studied elements. In particular, based on the study of international documents, namely the European Charter of Local Self-Government and the UN document "Transforming our world: the agenda for sustainable development until 2030", the concept of local self-government and its content as a phenomenon that plays an influential role in regulating relations arising from the delegation of state powers and local government.
Additionally, the essence of the method of abstraction is an imaginary distraction from insignificant properties, signs, connections, relations of the studied objects and phenomena in the simultaneous selection, fixation of one or more essential (interesting for the researcher) parties, properties of the object. Thus, its use was necessary to highlight the special features of local self-government in different countries, which in turn allowed to find those provisions that correspond to the features of private and public law.

With the help of the generalization method, the common features and properties of a particular class of objects are fixed, and the transition from single to general, from less general to more widespread, is carried out. In the context of this study, the method of generalization was used to summarize the theoretical studies of the content of private and public law and their comparison with the characteristics and essence of local selfgovernment.

Finally, the method of analogy makes it possible to establish the equivalence relationship between the two systems under consideration on some grounds. Any of these systems can actually exist or be abstract. If two or more phenomena, different in their physical nature, can be described by the same differential equation with the preservation of boundary conditions, then these phenomena are called similar. The method of analogies expands the possibilities of studying phenomena and has long been widespread. To study local self-government given the features of private and public law, a system of criteria for distinguishing between private and public law was used and transferred to the study of local self-government. Thus, along with the predominant predominance of features of public law, elements of private law were identified in the activities of local governments, such as the disposal of local government property.

\section{Results and Discussion}

\section{Public and private law: theoretical aspects}

Public and private law as an integral part of the theoretical basis of law, in general, is a multifaceted phenomenon, the study of which has a long history. The need for a historical digression of private law and its formation is since such studies will help optimize existing legislation, efficient application of private law, and provide a scientific basis for practical recommendations on the delimitation of 


\section{AMAZONDA}

regulatory areas between the main codified acts in private and public law.

The ancient doctrine of the law states that there are two types of legal relations, which are reflected in the laws of all states. The first of them defines the relations between fellow citizens, the existing connections between them. On their basis, private cases are resolved, they regulate the life of the community of people. Another type of such relationship determines how citizens should behave concerning society and the state. Laws governing private relations need to be soft and humane for the majority of the people. On the contrary, those underlying state laws should be cruel and severe, because only then can the damage that politicians can do to the majority of the people be limited (Trevett, \& Gagarin, 2011).

In ancient Rome, the need to divide the right into public and private was justified. The Roman jurist Ulpian argued that public law is what belongs to the state of the Roman state, private law is what belongs to the benefit of individuals, because there is a public benefit and a private benefit. private law must serve the benefit of individuals and their associations, and public law should serve the public good (Shabunina, 2006). Titus Livius emphasized that the laws of the XII tables, being a collection of all Roman law, were a source of public and private law (Muromtsev, 2003).

In the Middle Ages, the division of the right to private and public attention was not paid because of the characteristic events that took place in the conditions of the state. Private law was largely associated with public law, such as military duties, so full private legal capacity was associated with the public law prerequisite for combat capability (Radbruch, 1915).

Active development of legal thought took place in the period XVI-XVII centuries. During this period, the creation of new doctrines of law was based on the works of Roman lawyers. Thus, one of the most famous representatives of the French school Donell considered the main task of jurisprudence to derive general principles from Roman texts, abstracting from historical features. Commenting on Justinian's Code, he based the division of law into public and private. To public law, as opposed to private, he attributed all cases without which the state could not exist. To such cases, he attributed the birth of children. Characteristically, Donella had no doubt that the same case (at least the birth of children) can be considered both in terms of public and private law.

Hugo Grotius argued that "just as some communities are free from inequality, such as mutual relations of brothers, citizens, friends or allies, others are not free from inequality and, according to Aristotle, allow preference, for example, in the rights of parents over children, the master over the slave, the king over the subjects, God over the people, and one kind of justice consists in the relationship between equals and the other in the relationship between rulers and those who obey. Therefore, we are unlikely to be mistaken if we call this last species the right to rule, and the first - the right to equality (Grotius, 1994). XIX century became not only an era of comprehensive European codification but also a period of numerous scientific investigations of the issue we are studying. It should be noted that these processes are largely interconnected. For example, Merriman believes that the division of the right to public and private has an ideological basis, it is an expression of those areas of economic, social, and political thought that dominated in the XVII and XVIII centuries. and Germany in the XIX century. Codified civil law was at the heart of private law, and the dominant concepts of the relevant codes were individual private property and individual freedom of contract, protected from state interference. Merriman emphasizes that this ideology of liberalism was adopted by the legal teachings of the XIX century. He also emphasizes that one of the main achievements of the German Pandectists was the elevation of this ideology to a highly systematized and abstract level of legal science. They did it so well that these essential positions of the XIX century. were preserved in most European legal scholars of the XX century (Droniv, 2018).

Public and private law are opposite and, at the same time, interrelated phenomena. Their characteristics should be given with an indication of the subject, features, methods that are applicable to each of them (Skakun, 2001). The information is presented in the form of a table (Table 1) for a more accurate presentation of the main ideas. 
Table 1.

The features of public and private law. The information provided by Skakun (2001).

\begin{tabular}{|c|c|c|}
\hline Criterion & Public law & Private law \\
\hline By characteristics & $\begin{array}{l}\text { The subsystem of law, which: } \\
\text { 1) regulates relations between state } \\
\text { bodies or between individuals and the } \\
\text { state; } \\
\text { 2) provides public interest - focuses on } \\
\text { prohibitions, responsibilities of people } \\
\text { (subjects) to the state; } \\
\text { 3) ensures unilateral expression of the } \\
\text { will of the subjects of law; } \\
\text { 4) involves a broad scope of discretion; } \\
\text { 5) contains general and impersonal } \\
\text { norms that have a normative- } \\
\text { orientational influence; } \\
\text { 6) is characterized by the } \\
\text { predominance of directive-binding } \\
\text { rules, designed for hierarchical } \\
\text { relations of subjects and the } \\
\text { subordination of legal norms and acts; } \\
\text { 7) widely uses the latest techniques. }\end{array}$ & $\begin{array}{l}\text { The subsystem of law, which: } \\
\text { 1) regulates the relations of } \\
\text { individuals with each other; } \\
\text { 2) ensures the private interest: } \\
\text { focuses on economic freedom, free } \\
\text { self-expression, and equality of } \\
\text { producers, protection of owners } \\
\text { from the arbitrariness of the state; } \\
\text { 3) ensures the free expression of the } \\
\text { will of the subjects in the exercise of } \\
\text { their rights; } \\
\text { 4) involves the widespread use of a } \\
\text { contractual form of regulation; } \\
\text { 5) contains norms that are addressed } \\
\text { to subjective law and provide } \\
\text { judicial protection; } \\
\text { 6) is characterized by the } \\
\text { predominance of dispositive norms, } \\
\text { designed for self-responsibility for } \\
\text { their responsibilities and actions; } \\
\text { 7) retains the classic legal technique. }\end{array}$ \\
\hline By subject & $\begin{array}{l}\text { Sphere of "public affairs": the sphere } \\
\text { of structure and activity of the state as } \\
\text { a public authority, all public } \\
\text { institutions, the state apparatus, } \\
\text { administrative relations, civil service, } \\
\text { criminal prosecution and } \\
\text { responsibility, principles, norms, and } \\
\text { institutions of interstate relations and } \\
\text { international organizations, etc. }\end{array}$ & $\begin{array}{l}\text { Sphere of "private affairs": the } \\
\text { sphere of the status of a free person, } \\
\text { private property, free contractual } \\
\text { relations, inheritance, free } \\
\text { movement of goods, services and } \\
\text { funds, etc. }\end{array}$ \\
\hline By method & Imperative & Dispositive \\
\hline
\end{tabular}

Legal science has many criteria for distinguishing between private and public law, which can be systematized by giving the Table 2 .

Table 2.

The main criteria for distinguishing between public and private law.

\begin{tabular}{lll}
\hline Criterion & Public law & Private law \\
\hline & $\begin{array}{l}\text { A person who enters into public } \\
\text { relations for the exercise of } \\
\text { public authority (state bodies, } \\
\text { local governments, their officials } \\
\text { and officials authorized by them) }\end{array}$ & $\begin{array}{l}\text { Individuals, entrepreneurs and legal } \\
\text { entities }\end{array}$ \\
& $\begin{array}{l}\text { Relations of subordination with } \\
\text { possible exceptions (for example, } \\
\text { relations of executive bodies and } \\
\text { local self-government bodies, } \\
\text { Legal status of the }\end{array}$ & Legal and factual equality of \\
& pabjects of relations & partipants \\
& the exercise of delegated powers) & \\
\hline
\end{tabular}


The content of legal relations
The parties to the relationship operate within the rules established by law
Public legal relations due to the existence of subordination of individuals to the will of the authorities, exercised in public authority, should be considered by the court given the comprehensive protection of the rights of the weaker party in the relationship (individual).

Interests are based on ensuring the public good
The emergence of private rights and obligations from actions that may or may not be provided by law. The manner of exercising private rights and obligations (even) defined by law, is only a desirable form of conduct of participants in private relations, and its non-compliance will not entail any legal consequences if the actions correspond to the essence and content of the respective private relations and do not violate prohibitions.

Private relations, which are characterized by equality of their participants, are subject to consideration in court based on impartiality and full implementation of adversarial and dispositive.

Interests arise to ensure the wellbeing of the individual legal relations emerge (for example, on labor law issues) (Biryukova, 2018).

analysis of the works of such scholars as Sanzharuk (2006), Banchuk (2011), Rabinovych (2004), Mamutov (1999), Nesterenko (2016), and Chepis (2010).

From the above, it is necessary to summarize:

- private law can be defined as a set of rules and regulations relating to the status and protection of the interests of individuals who do not have power, are not in a relationship of subordination, equally and freely establish their rights and obligations in relations arising from their initiative;

- the definition of public law is based on its imperative method, according to which the behavior of subjects is regulated by law, the possibility of applying the prohibition of action as a method of shaping the behavior of individuals and legal entities;

- the boundaries between private and public law have never been unambiguously defined and are constantly changing. Private law does not actually exist without the public, because the public is designed to protect and defend private relations. Private law is based on public law, without which it could be devalued. In addition, in the process of historical development, the boundaries between them are blurred and mixed private-

\section{Local self-government as a special subject of private-law and public-law relations: international practice}

The European Charter of Local Self-Government understands local self-government as the actual ability of local self-government bodies to regulate a significant part of public disputes and manage the territorial community, acting within the law, with a special responsibility and in the interests of the local population (Council of Europe, 1985).

One of the goals of sustainable development of the United Nations for 2016-2030 is devoted to the issue of community development testifies to the significant attention of the world community to matters related to local self-government. Goal 11 is to ensure the openness, security, sustainability, and environmental sustainability of cities and towns (United Nations, 2015).

The presence of local self-government is one of the hallmarks of a democratic state. At the international level, local self-government is represented by the United Cities and Local Governments (UCLG) (2021), whose main functions are to protect local self-government at the global level, to promote its values, goals, and 
interests through cooperation between local authorities and within the wider international community.

The responsibilities of local government under the UCLG include (United Cities and Local Governments, 2013):

- services (water supply, sewage and solid waste collection, public transport, street lighting, street cleaning, markets and public places, public toilets, pollution control, some aspects of childcare and school education, libraries and cultural events, some forms provision of social security (usually in conjunction with higher authorities), fire services and emergency response (usually in conjunction with higher authorities), registration of births and deaths, monitoring of infectious diseases, cemeteries, and, in many countries, protection health, education, housing and maintenance of order);

- infrastructure (water supply network, sewerage, surface drainage systems, local roads, footpaths, bridges, landfills, wastewater treatment, bus stations, parks, squares, sports facilities, public places);

- buildings (building codes and regulations, management of technical operation of public buildings, rental rules);

- urban planning (land use management and application of land-use rules, infrastructure expansion plans);

- others (local economic development, tourism), etc.

At the regional level, the largest organization representing the interests of European local authorities and their associations in more than 40 countries is the Council of European Municipalities and Regions (CEMR) (2021). CEMR members are national associations of local and regional governments, which include members of municipalities, cities, and regions in their countries.

Local governments as holders of power have the following characteristics (Karpa, 2017):

- are formed by the state or the people following the law and act on its basis;

- have public functions that are aimed at satisfying the public interest;

- have an organizational structure;

- interact with other subjects of power;

- have a specific subordinate and territorial nature of the activity.
All the above features are somehow inherent in the local self-government of different legal systems.

It is proposed to make a general description of the most striking examples of the organization of local self-government and on its basis to investigate the private-law and public-law aspects of this institution.

The Anglo-American legal system creates a specific organization of local government in the United States and Great Britain.

The development of local self-government in Great Britain dates back to the Anglo-Saxon period, when the Germanic tribes who settled in the Roman province of Britain brought with them the preserved communal order, based on which the primary structure of local self-government was formed (Aranovskyi, 2000). The activity of local self-government in Great Britain is regulated by a special law on local selfgovernment (Local Government Act), adopted in 1974 (Law No. 66, 1974). With further changes in 2000. According to this normative act, in each administrative unit, if it has more than 150 voters, the local population elects a council for a term of 4 years. If the administrative unit has less than 150 voters, a general meeting of voters is used, where issues that are not considered by higher councils are resolved. Each local council forms profile committees, whose main activities are issues related to finance, education, roads, social assistance, and other matters at the local level (Shpak, 2014a).

In the system of municipal government in the UK, the bearers of power are only councils, the powers of other units of the municipal apparatus are considered as derivatives. The main feature of local government in the UK is the combination of councils of general leadership and operational and executive activities (Kuzmenko, 2014).

The system of local self-government in the United States is more complex in its organization.

The specifics of local government in the United States are determined by the peculiarities of the administrative-territorial division. As you know, the United States is a federal state. Each state has its laws, which must not contradict national laws.

Given the above, in the United States, there are local governments of general and special competence. 


\section{AMAZONDA}

The system of local self-government bodies of general competence is built based on administrative-territorial division. Each state is divided into counties, in which the system of selfgovernment is determined by the constitutions and laws of the states. There are two types of county councils: the board of commissioners and the board of supervisors. The first includes the management of all practical work in specific areas, the second provides for the representation

Table 3.

Two basic rules to determine the powers of local governments in the United States. The information provided by Kuzmenko (2014).

\begin{tabular}{ll}
\hline Name of the rules & Relevant powers of local self-government \\
\hline & Powers: \\
& - provided by law in clear words; \\
& - which are necessarily and fairly considered and \\
& characterized by the powers granted by law; \\
Dillon's rule & - which are valuable and necessary for the creation of \\
& a municipality. \\
& Source of authority: authorized charter of the \\
Home rule (delegation of rights to self- & lehistratury \\
government) &
\end{tabular}

One of the most significant issues dealt with by local authorities is social services: school education, social security, librarianship, landscaping, organization of recreation areas, and quality control of goods.

The second place in terms of the functions of local self-government bodies of municipalities is occupied by the administrative and administrative sphere: law enforcement, police management, justice, fire safety, tax collection, elections, and conducting civil status acts.

The third group of powers is the economic sphere. Municipalities manage their enterprises and services, manage their property, as well as indirectly regulate the activities of private enterprises, build housing, and set rental rates for their property. Property management is seen as a power that can be regarded as an area of private law, as it is governed by civil law.

The state can give municipalities the right to exercise their powers based on the principle of self-government. Thus, local authorities are given the right to independently, without state intervention:

- develop, adopt and amend its charter of selfgovernment;

- exercise all the powers of local government, except for the restrictions established by the state constitution and federal laws (Kuzmenko, 2014). in the council of elected officials of municipalities within the county. The council has the right to impose local taxes and fees, adopt and control the budget, monitor the organization and conduct of elections, and etc. (Chaplya, 2014).

Two basic rules are used to determine the powers of local governments in various municipalities in the United States (Kuzmenko, 2014) (Table 3). the states that are part of the Romano-Germanic legal system, the experience of France is impressive.

The activity of local self-government in France is regulated by Law No. 82-213 "On the rights and freedoms of communes, departments, and regions" of March 2, 1982. This law defines the powers of municipalities, departments, regions, and the state in the allocation of state resources and transfer of public funds to local authorities. The law determines local authorities, the election regime and the status of elected representatives, the conditions of cooperation between municipalities, districts, and regions, as well as the level of citizen participation in local life.

Given the peculiarities of the administrativeterritorial division of France, it is possible to distinguish local governments of the commune, department, and region.

The local authorities of the commune are municipal councils. Their powers include (Vorona, 2009):

- financial (adoption of the budget, determination of municipal tax rates, resolving issues on the need for loans, approval of reports on the use of budget funds); 
- $\quad$ in the field of public services (the council has the right to create or liquidate public services of the commune);

- in respect of the property of the commune, which is divided into "public", i.e. such that is intended for public use, and "private", which the commune disposes of as a private owner.

It should be noted that the "private" property of the commune has the features of private law. Thus, municipal councils enter into civil law relations, for example, by concluding a lease agreement for a land plot owned by it. In this case, the council acts as a legal entity.

- powers in the field of landscaping and urban construction.

The municipal council is under the administrative control of the central government.

The department in France is the second level of the administrative and territorial organization after the commune. In contrast to the commune, at its level two authorities operate in parallel, namely the General Council as a body of selfgovernment and the Prefect as a body of state power.

The powers of the municipal administration of the department include:

- approval of the budget and report on its implementation;

- determination of the department's development policy;

- setting internal tax rates of the department;

- creation of public services of the department and establishment of general rules of their functioning;

- determination of the staff of the department's services;

- making decisions on all property of the department.

The department is a principal link in the system of state executive power. This is the level where the local state administration operates. This administration is headed by a prefect - a representative of the state at the regional level, and the administration itself is endowed with fairly large powers and includes a system of essential services that ensure the implementation of public policy at the regional level (Vorona, 2008). The main representative body of the region is the regional council, whose members are elected by general and direct elections according to the proportional electoral system.
The main competencies of regional councils include the adoption of the regional budget, control over the implementation of the regional development plan, the activities of regional bodies and structures (Chirkiv, \& Kushnir, 2020).

For a clearer and more contrasting example of local government, it is advisable to describe the main features of the Japanese system of local government.

According to the Constitution of Japan of May 3, 1947, the provisions on the organization and operation of local public authorities are established by law following the principle of local autonomy. A special regulation governing the activities of local self-government in Japan is the Law on Local Autonomy of April 17, 1947 (Law No. 67, 1947).

The literature identifies the principles of local government in Japan:

- the principle of local autonomy;

- autonomy of the local community;

- autonomy of residents.

notes that the principle of local autonomy separates the autonomy of the administrativeterritorial unit from the state, the autonomy of the local community is related to the internal organization and forms of administrativeterritorial units and provides for the management of the community, residents on its territory, the autonomy of residents is determined by the procedure of local referendum (Baglaya, Leibo, \& Entina, 2008).

Thus, the local self-government of Japan is characterized by independence as a whole and the independence of each resident, which in turn indicates a sufficiently developed independence of territorial units and their ability to solve problems without the influence of central authorities, both by their own forces and by expressing the will of the community of the territorial unit.

As for the structure of local self-government in Japan, it has a two-tier system. The first link is prefectures, the second - municipalities.

The main links of local government are prefectural, urban settlement, and village assemblies. Their powers include, in particular, the adoption of the budget, the establishment of taxes, and educational activities. 


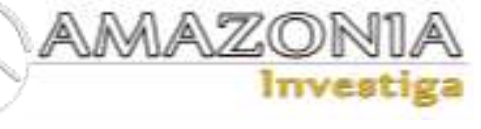

Describing the functions of municipalities, Lisnychy (2004) notes that they are related to addressing the daily needs of the local population, such as providing the population and public utilities, ensuring the efficiency of educational and health care institutions, monitoring the sanitary condition of the territory, ensuring the work of social services, repair and maintenance of buildings and structures, ensuring the smooth operation of transport, support for self-organization population, and staffing of the local municipal service.

It is necessary to note that in Art. 94 of the Constitution of Japan (1947) stipulates that local authorities have the right to manage their property, conduct business, and carry out administrative management. In addition, they can issue their decisions within the law (Chaplya, 2014).

Thus, based on the analysis of local government systems in countries such as the United Kingdom, the United States, France, and Japan (which is different legal systems), we can conclude that the actual separation of local government with certain features, such as government control over local government (Law No. 66, 1974), administrative control (France), obedience to national laws (USA). The most autonomous is the activity of local governments in Japan.

\section{Conclusions}

As a result of the study, the role of local selfgovernment in public and private law was clarified and the following was established:

1. Local self-government, acting as a subject of public law, has the following characteristics:

- activities regulated by law;

- focus on ensuring the functioning of society;

- the right to establish mandatory rules in the controlled area;

- has delegated powers of state power.

2. As a subject of private law, local selfgovernment is endowed with the right to dispose of its property while entering into civil law relations. Furthermore, as a legal entity of private law, local governments have the right to join associations, hold conferences.

3. Private law may be defined as a right aimed at protecting the interests of individuals who do not have power, are not in a relationship of subordination, equally and freely establish their rights and obligations in relations arising from their initiative.

4. The boundaries between private and public law are not clearly defined. There is a relationship between private law and public law, and private law does not actually exist without public law, because public law is designed to protect and defend private relations. Private law is based on public law, without which it could be devalued.

5. The international experience of countries such as the United Kingdom, the United States, France, and Japan, which are part of different legal systems shows the separation of local governments with certain features, such as control of public authorities over local government (UK), administrative control (France), obedience to national laws (USA). The most autonomous is the activity of local governments in Japan.

In summary, it can be argued that the predominance of public law over private in the activities of local government.

Regarding further scientific research, it is essential to examine the features of the manifestations of local self-government as private law and public law through the prism of international experience.

\section{Bibliographic references}

Aranovskyi, K.V. (2000). State law of foreign countries. Moscow: Forum-Info. ISBN 5-81990009-X.

Baglaya, M.V., Leibo, Yu.I., \& Entina, L.M. (Eds.). (2008). Constitutional law of foreign countries. Moscow: Norma.

Baltsiy, Yu. Yu. (2020). On the definition of local self-government of Ukraine. Odessa: Helvetica. https://hdl.handle.net/11300/12930

Banchuk, O. (2011). Grounds for distinguishing between public and private law in Ukraine. Public law, 2, 118-120.

Biryukova, A.G. (2018). The ratio of private and public law: a dualistic aspect. Law and Society, 4, 76-80.

Chaplya, O.V. (2014). Municipal administration in the USA: an overview. Legal Scientific Electronic Journal, 4, 12-18. Recovered from http://www.1sej.org.ua/4_2016/9.pdf.

Chepis, O.I. (2010). The value of private and public interests for the formation of civil law. Scientific Bulletin of Uzhgorod University, 13, 261-265.

Chirkiv, A., \& Kushnir, V. (2020). Features of local self-government in France. Entrepreneurship, Economy and Law, 5, 176-180 
Council of Europe. (1985). European Charter of Local Self-Government. Recovered from https://www.coe.int/en/web/conventions/fulllist/-/conventions/treaty/122

Droniv, B.M. (2018). The interaction of private and public law: modern continental European theory and practice. Kharkiv: Pravo. Recovered from https://pravoizdat.com.ua/image/data/Files/613/3_Vzaemovp liv\%20privatnogo $\% 20 \mathrm{i} \% 20$ publichnogo $\% 20$ pra va_vnutri.pdf

Grotius, G. (1994). On the law of war and peace. Three books explaining the natural law and the law of peoples, as well as the principles of public law. Moscow: Ladomir. Recovered from http://grachev62.narod.ru/huig_de_groot/conten t.html

Karpa, M. (2017). Limits of competence of subjects of public service: features of definition // Public administration and local selfgovernment, 2, 109-116. Recovered from http://nbuv.gov.ua/UJRN/dums_2017_2_16

Kharytonova, O.I. (2002). Division of law into public and private: theoretical aspects. Bulletin of the Khmelnytsky Institute of Regional Management and Law, 1, 3-6. Recovered from http://old.univer.km.ua/visnyk/38.pdf

Kuzmenko, O.V. (2014). Administrative law of foreign countries. Kyiv: Yurinkom Inter. ISBN 978-966-667-718-4

Law No. 66, Local Government Act. Great Britain, November 8, 1974. Recovered from https://www.legislation.gov.uk/ukpga/1974/7/co ntents

Law No. 67, Local Autonomy Act. Japan, April 17, $1947 . \quad$ Recovered from https://hourei.ndl.go.jp/\#/detail?billId=0092120 24

Law No. 82-213, on the rights and freedoms of municipalities, departments and regions. France, Paris of March 2, 1982. Recovered from http://www.legifrance.gouv.fr/affichTexte.do?ci dTexte=JORFTEXT000000880039

Lisnychy, V.V. (2004). Political and administrative systems of foreign countries. Kyiv: Professional Publishing House.

Mamutov, V. (1999). On the question of the concept of private law. Bulletin of the Academy of Legal Sciences of Ukraine, 2, 15-25.

Muromtsev, S.A. (2003). Civil law of Ancient Rome. Moscow: Statut, 2003. Recovered from http://lawlibrary.ru/izdanie50009.html

Nesterenko, A.S. (2016). Public and private law as a basis of legal centralization and decentralization in financial law. Scientific herald of the International Humanities University: Jurisprudence, 19, 40-42. Recovered from http://www.vestnikpravo.mgu.od.ua/archive/juspradenc19/12.pdf
Rabinovych, P.M. (2004). Private and public law as a dialectical unity. Problems of state formation and protection of human rights in Ukraine. Lviv: Ivan Franko National University of Lviv.

Radbruch, G. (1915). Introduction to the science of law. Moscow: Trud.

Rovinska, K.I. (2013). Principles of the European Charter of Local Self-Government as a Basis for the Formation of Local SelfGovernment in Ukraine. State building, 1, 1-14. Recovered from http://nbuv.gov.ua/UJRN/DeBu_2013_1_31 Sanzharuk, T.O. (2006). Subjects of law in the field of private law. Actual problems of state and law, 1, 54-57. Recovered from http://www.apdp.in.ua/v29/11.pdf

Shabunina, V.V. (2006). The division of law into public and private in Roman law. Republican Interdepartmental Scientific Collection, 77, 1421. Recovered from http://library.nlu.edu.ua/POLN_TEXT/PROBL EM/Pr_zak77.htm

Shpak, Y.O. (2014a). Organization of local selfgovernment of Japan. State building and local self-government, 27, 227-236. Recovered from http://irbis-nbuv.gov.ua/cgi-

bin/irbis_nbuv/cgiirbis_64.exe?C21COM=2\&I2 $1 \mathrm{DBN}=\mathrm{UJRN} \& \mathrm{P} 21 \mathrm{DBN}=\mathrm{UJR}$ N \&IMAGE_FIL E_DOWNLOAD $=1 \&$ Image_file_name $=P D F / d$ bms_2014_27_20.pdf

Shpak, Y.O. (2014b). The experience of reforming local self-government in Great Britain. Scientific Bulletin of the International Humanities University: Jurisprudence, 10(1), 8284. Recovered from http://nbuv.gov.ua/UJRN/Nvmgu_jur_2014_10$1 \% 281 \% 29 \_24$

Skakun, O.F. (2001). Theory of State and Law. Kharkiv: Konsum.

The Constitution of Japan. Art. 92. November 3, 1947 (Japan). Recovered from http://www.sangiin.go.jp/eng/law/tcoj/index.ht $\mathrm{m}$

The Council of European Municipalities and Regions (CEMR). (2021). The official website. Recovered from http://www.ccre.org

Trevett, J., \& Gagarin, M. (Transl.). (2011). Demosthenes, Speeches 1-17. Ostin: University of Texas Press. Recovered from http://www.jstor.org/stable/10.7560/726772.

United Cities and Local Governments (UCLG). (2021). The official website. Recovered from https://www.uclg.org/en/organisation/about United Cities and Local Governments. (2013). Basic Services for All in an Urbanizing World, Third Global Report of United Cities and Local Governments on Local Democracy and Decentralization, GOLD III Executive Summary. Barcelona: ITD. Recovered from 
https://www.uclg.org/sites/default/files/re_gold_ eng.pdf

United Nations. (2015). Sustainable Development Goals 2016-2030. Recovered from https://ukraine.un.org/uk/sdgs

Vorona, P.V. (2008). features of local selfgovernment of France on the example of regional administrative-territorial units - departments: experience for Ukraine. State building, 2, 1-5. Recovered

from https://core.ac.uk/download/pdf/300236453.pdf Vorona, P.V. (2009). Commune as a basic link of local government in France. Academic papers collection, 3, 1-8. Recovered from http://lvivacademy.com/vidavnitstvo_1/visnik3/ fail/+Vorona.pdf 